\title{
Literature Review: Perbandingan Efektivitas Platelet Rich Plasma (PRP) dengan Asam Hialuronat (HA) sebagai Terapi Osteoarthritis
}

\section{Literature Review: Comparison Effectiveness of Platelet Rich Plasma (PRP) vs Hyaluronic Acid as Therapy of Osteoarthritis}

\author{
Bella Pratiwi Anzani \\ Fakultas Kedokteran, Universitas Lampung, Indonesia
}

\section{ARTICLE INFO}

Article history:

Received date

24 Jan 2020

Revised date

26 Feb 2020

Accepted date

24 Apr 2020

\section{Keywords:}

Hyaluronic acid;

Osteoarthritis;

Platelet rich plasma.

\begin{abstract}
ABSTRAK
The prevalence of osteoarthritis is increasing with age. In osteoarthritis, there is a change in the joint process that fails to repair damaged cartilages and manifestations such as joint narrowing, osteophytosis, subcondral sclerosis, and abnormal bone shape. Pharmacological therapies such as analgesics, corticosteroids, glucosamine, chondroitin sulfate, and non-steroidal anti-inflammatory drugs are used together with viscosupplementation to help and improve the development of arthritis. Intra-articular injection therapy is also used as a good choice for osteoarthritis therapy. Hyaluronic acid (HA) and platelet-rich plasma (PRP) are the two choices of intraarticular therapy that can be used. Hyaluronic acid can reshape cartilage through aggregation with proteoglycans and can improve synovial fluid present in the joints, but therapy with hyaluronic acid has a long-lasting, expensive, and proven effect. Platelet-rich plasma (PRP) is a new therapy. PRP is obtained from blood centrifugation several times. PRP is very easy to get, cheap and non-invasive. PRP contains various growth factors that can regenerate damaged cartilages. PRP can be applied and has the same benefits as HA, but until now there has been no consensus that which is a better outcome between the two therapies. From various literature it is known that PRP is more effective than hyaluronic acid as osteoarthritis therapy.
\end{abstract}

Prevalensi osteoarthritis prevalensinya semakin meningkat seiring dengan bertambahnya usia. Pada osteoarthritis, terjadi perubahan proses biologi sendi yang mengakibatkan gagalnya perbaikan kartilago yang rusak dan muncul manifestasi seperti penyempitan celah sendi, osteofitosis, sklerosis subkondral, dan abnormalitas bentuk tulang. Diperlukan terapi farmakologis seperti analgesik, kortikosteroid, glukosamin, kondroitin sulfat, dan obat antiinflamasi non-steroid yang digunakan bersama dengan viscosupplementation untuk meringankan gejala serta memperlambat perkembangan arthritis. Selain itu terapi injeksi intraartikular juga digunakan sebagai pilihan yang baik untuk terapi osteoarthritis. Asam hialuronat (HA) dan platelet rich plasma (PRP) adalah dua pilihan terapi intraartikular yang dapat digunakan. Asam hialuronat dapat membentuk kembali matriks kartilago melalui agregasi dengan proteoglikan serta dapat memperbaiki cairan sinovial yang ada pada sendi, namun terapi dengan asam hialuronat memiliki efek yang tidak tahan lama, mahal dan efek modifikasi struktural belum terbukti. Platelet rich plasma (PRP) merupakan suatu terapi baru. PRP didapatkan dari hasil sentrifugasi darah dalam beberapa kali. PRP sangat mudah didapat, harga murah dan non invasif. PRP mengandung berbagai growth factor yang dapat meregenerasi kartilago yang rusak. PRP dapat diterapkan dan memiliki manfaat yang hampir sama dengan HA, namun sampai saat ini belum ada konsensus yang menyatakan mana outcome yang lebih baik diantara kedua terapi tersebut. Dari berbagai literatur diketahui bahwa PRP lebih efektif dibandingkan asam hialuronat sebagai terapi osteoarthritis.

Corresponding Author:

Bella Pratiwi Anzani

Fakultas Kedokteran, Universitas Lampung, Indonesia

Email: bellapratiwi789@gmail.com 


\section{PENDAHULUAN}

Osteoarthritis menempati urutan kelima penyebab disabilitas tertinggi di dunia. Osteoarthritis merupakan salah satu penyakit degeneratif kronis pada sendi yang dapat mempengaruhi kualitas hidup. Sendi tubuh yang paling sering terkena osteoarthritis yaitu sendi pada vertebra, panggul, lutut dan pergelangan kaki. Prevalensi penyakit ini cukup tinggi di dunia dan lebih banyak terjadi pada wanita. Prevalensi pada laki-laki yaitu sebesar 9,6\% dan pada wanita sebesar $18 \%$. Penyakit ini umumnya terjadi pada usia diatas 60 tahun dan prevalensinya semakin meningkat seiring dengan bertambahnya usia (Conte, et al., 2008; Raeissadat, et al., 2017; Soeroso, et al., 2009).

Selama ini osteoarthrtitis (OA) dipandang sebagai proses penuaan yang tidak dapat dihindari. Para ahli berpendapat bahwa OA merupakan penyakit gangguan homeostasis dan metabolisme kartilago dengan kerusakan struktur proteoglikan yang penyebabnya belum jelas diketahui. Adanya jejas mekanis dan kimiawi pada sinovial sendi dapat menimbulkan OA. Jejas tersebut multifaktorial, antara lain faktor umur, stress mekanis, penggunaan sendi berlebihan, defek anatomis, obesitas, genetik, humoral, dan faktor kebudayaan. Prevalensi dan beratnya OA semakin meningkat dengan bertambahnya umur. OA hampir tak pernah pada anak-anak, jarang pada umur dibawah 40 tahun dan sering pada umur diatas 60 tahun. Stress mekanis yang menjadi faktor risiko OA dapat juga disebabkan karena cedera sendi, pekerjaan dan olahraga. Pekerjaan berat atau pemakaian satu sendi yang terus-menerus, misalnya tukang pahat dan pemetik kapas, berkaitan dengan risiko OA. Aktivitas tertentu juga dapat menjadi predisposisi OA cedera traumatik misalnya robeknya meniscus, ketidakstabilan ligamen yang dapat mengenai sendi (Soeroso, et al., 2017).

Etiologi osteoarthritis berdasarkan patogenesisnya dibedakan menjadi osteoarthritis primer dan osteoarthritis sekunder. Osteoarthritis primer belum diketahui penyebabnya serta tidak berhubungan dengan penyakit sistemik dan perubahan lokal sendi. Sedangkan osteoarthritis sekunder dapat disebabkan karena kelainan endokrin, metabolik, infeksi, imobilisasi yang terlalu lama, jejas mikro dan makro, pertumbuhan dan herediter. Pada osteoarthritis, terjadi perubahan proses biologi pada sendi yang akan mengakibatkan gagalnya perbaikan kartilago yang rusak sehingga dapat muncul manifestasi seperti penyempitan ruangan sendi, osteofitosis, sklerosis subkondral, terbentuk kista, dan abnormalitas bentuk tulang (Arden \& Nevitt, 2006).

Diperlukan terapi farmakologis untuk osteoarthritis seperti analgesik, kortikosteroid, glukosamin, kondroitin sulfat, dan obat antiinflamasi non-steroid digunakan bersama dengan viscosupplementation untuk menghilangkan rasa sakit dan gejala serta memperlambat perkembangan arthritis. Selain itu terapi injeksi intraartikular juga digunakan sebagai pilihan yang baik untuk terapi osteoarthritis. Asam hialuronat (HA) dan platelet rich plasma (PRP) adalah dua pilihan terapi intraartikular yang dapat digunakan (Sadabad, et al., 2016).

HA adalah glikosaminoglikan alami dan merupakan komponen cairan sinovial dan matriks kartilago. Cairan sinovial dengan HA normal berfungsi pelumas dan peredam kejut (shock absorber). Injeksi HA diperkirakan bisa mengembalikan viskoelastisitas cairan sendi lutut, sehingga dapat memperbaiki fungsi sendi lutut yang terkena OA. AAOS (American Academy of Orthopaedic Surgeons) pada tahun 2013 tidak merekomendasikan penggunaan viskosuplementasi HA pada kondisi OA simptomatik. Asam hialuronat dapat membentuk kembali matriks kartilago melalui agregasi dengan proteoglikan serta dapat memperbaiki cairan sinovial yang ada pada sendi. Namun asam hialuronat memiliki kekurangan yaitu efeknya tidak tahan lama, mahal dan efek modifikasi struktural belum terbukti (Say \& Yener, 2013; Wijaya, 2018).

Pengobatan dengan HA disarankan untuk pengobatan OA lanjut sebelum intervensi bedah atau dapat juga dipakai sebagai terapi alternatf jika terapi dengan NSAID atau kortikosteroid tidak berhasil. Skema terapeutik dari suplementasi HA bervariasi sesuai dengan berat molekul. Namun menurut literatur pada umumnya, injeksi HA diberikan satu kali dalam seminggu selama tiga hingga lima minggu (Cerza, et al., 2012).

Platelet rich plasma (PRP) merupakan suatu terapi baru. PRP dapat diterapkan dan memiliki manfaat hampir sama dengan HA. PRP sangat mudah didapat, harganya murah dan non invasif. PRP mengandung berbagai growth factor seperti transforming growth factor beta, basic fibroblast growth factor, platelet derived growth factor, epidermal growth factor, vascular endothelial growth factor, dan connective tissue growth factor yang dapat meregenerasi kartilago yang rusak (Soeroso, et al., 2009; Spaková, Rosocha, Lacko, Harvanová, \& Gharaibeh, 2012). Bahan dasar PRP adalah darah. PRP 
merupakan sebuah plasma autolog yang memiliki konsentrasi platelet diatas rerata. PRP mengacu pada konsentrasi platelet dalam plasma lebih tinggi dari platelet normal yang beredar dalam tubuh. Dalam keadaan fisiologis, jumlah platelet dalam darah terbentang dari 150,000/ $\mu$ l hingga $350,000 / \mu 1$. PRP kemudian didefinisikan sebagai konsentrasi 1,000,000 platelets/ $\mu \mathrm{l}$ dalam $5 \mathrm{ml}$ volume plasma (Widyadharma, 2013).

Modalitas terapi PRP telah memunculkan banyak penelitian dalam beberapa tahun terakhir. Salah satu studi yang membandingkan antara efektifitas terapi PRP dan high moleculer weight hyaluronic acid (HMWHA). Pada penelitian ini peneliti memberikan injeksi PRP intra artikular pada 30 pasien dan 30 pasien dengan HMWHA dosis tunggal. Hasil yang didapatkan terdapat $40 \%$ pasien menyatakan mengalami penurunan skala nyeri, dimana $33 \%$ diantaranya merupakan kelompok pasien yang mendapatkan injeksi PRP intra-artikuler (Widyadharma, 2013).

Sampai saat ini belum ada konsensus yang menyatakan mana outcome yang lebih baik diantara kedua terapi tersebut. Oleh karena itu, penulisan artikel ini bertujuan untuk membandingkan efektivitas dari platelet rich plasma (PRP) dan asam hialuronat sebagai terapi osteoarthritis. Manfaat yang didapat dari penulisan artikel ini yaitu dapat menjadi bahan referensi dalam memilih terapi yang paling efektif untuk tatalaksana osteoarthritis.

\section{PEMBAHASAN}

Osteoarthritis adalah salah satu penyakit kronis terbanyak pada kelainan sendi dan penyakit ini juga merupakan penyebab utama dari kesakitan dan disabilitas di sebagaian besar negara di dunia (Fransen, et al., 2014). Sekitar $10 \%$ penderita osteoarthritis mengalami disabilitas. Usia merupakan faktor risiko terjadinya $\mathrm{OA}$, makin bertambahnya usia, makin tinggi kemungkinan untuk terkena OA. Seiring dengan meningkatnya usia harapan hidup, menurut WHO pada tahun 2025 populasi usia lanjut di Indonesia akan meningkat $414 \%$ dibanding tahun 1990. Dapat dikatakan bahwa faktor risiko osteoarthritis di Indonesia akan semakin meningkat (Indonesian Rheumatology Association, 2014).

Osteoarthritis memiliki banyak faktor risiko. Faktor risiko osteoarthritis terdiri dari faktor risiko sistemik dan faktor risiko lokal. Faktor risiko sistemik yaitu umur, jenis kelamin, hormon, etnis, kongenital dan diet. Sedangkan yang termasuk faktor risiko lokal yaitu obesitas, trauma, aktivitas fisik, pekerjaan, faktor mekanis dan kelemahan lutut. Faktor risiko tersebut akan menimbulkan jejas mekanis dan kimiawi pada sinovial sendi yang akan merangsang terbentuknya molekul abnormal dan produk degradasi kartilago yang berada di dalam cairan sinovial sendi. Proses ini akan mengakibatkan terjadinya inflamasi, kerusakan kondrosit dan rasa nyeri pada sendi (Soeroso, et al., 2009; Zhang \& Jordan, 2011).

Hipertrofi kartilago dapat menandakan terjadinya osteoarthritis karena hal ini berhubungan dengan keterbatasan peningkatan sintesis makromolekul oleh kondrosit sebagai kompensasi perbaikan (repair). Proses repair ini dipengaruhi oleh faktor pertumbuhan (growth factor) yang mengontrol proliferasi sel dan komunikasi antarsel. Growth factor akan menginduksi kondrosit untuk mensintesis asam deoksirobonukleat (DNA) dan protein seperti kolagen dan proteoglikan. Growth factor yang berperan yaitu insulin-like growth factor (IFG-1), growth factor, transforming growth factor $b$ (TGF $\beta$ ), dan coloni stimulating factors (CSFs). IGF-1 berperan penting dalam proses repairrawan sendi dan sensitivitas sel terhadap IGF-1 menjadi berkurang ketika terjadi inflamasi. TGF $\beta$ memiliki efek untuk merangsang sintesis kolagen dan pretoeglikan serta menekan stromelisin yang merupakan enzim yang mendegradasi proteoglikan, meningkatkan sintesis prostaglandin $\mathrm{E}_{2}\left(\mathrm{PGE}_{2}\right)$ dan melawan efek inhibisi $\mathrm{PGE}_{2}$ oleh interleukin 1 (IL-1) (Conte, et al., 2008; Soeroso, et al., 2009).

Dalam menegakkan diagnosis OA dipergunakan acuan berupa kriteria berdasarkan criteria American College of Rheumatology (ACR) yang membagi OA menjadi OA lutut, OA tangan dan OA panggul (Indonesian Rheumatology Association, 2014). 
Tabel 1. Kriteria Diagnosis OA Lutut Berdasarkan ACR

\begin{tabular}{|c|c|c|}
\hline $\begin{array}{c}\text { Berdasarkan Kriteria } \\
\text { Klinis }\end{array}$ & $\begin{array}{c}\text { Berdasarkan Kriteria Klinis } \\
\text { dan Radiologis }\end{array}$ & $\begin{array}{c}\text { Berdasarkan Kriteria Klinis dan } \\
\text { Laboratoris }\end{array}$ \\
\hline $\begin{array}{l}\text { Nyeri sendi lutut, dan } \\
\text { paling sedikit } 3 \text { dari } 6 \\
\text { kriteria di bawah ini: } \\
\text { 1. Krepitus saat gerakan } \\
\text { aktif Kaku sendi < } 30 \\
\text { menit } \\
\text { 2. Usia >50 tahun } \\
\text { Pembesaran tulang } \\
\text { sendi lutut } \\
\text { 3. Nyeri tekan tepi tulang } \\
\text { 4. Tidak teraba hangat } \\
\text { pada sinovium sendi } \\
\text { lutut. }\end{array}$ & $\begin{array}{l}\text { Nyeri sendi lutut dan adanya } \\
\text { psteofit, serta paling sedikit } 1 \\
\text { dari } 3 \text { kriteria di bawah ini: } \\
\text { 1. Kaku sendi }<30 \text { menit } \\
\text { 2. Usia }>50 \text { tahun } \\
\text { 3. Krepitus pada gerakan sendi } \\
\text { aktif }\end{array}$ & $\begin{array}{l}\text { Nyeri sendi lutut dan paling sedikit } 5 \\
\text { dari } 9 \text { kriteria berikut ini: } \\
\text { 1. Usia }>50 \text { tahun } \\
\text { 2. Kaku sendi }<30 \text { menit } \\
\text { 3. Krepitus pada gerakan aktif } \\
\text { 4. Nyeri tekan tepi tulang } \\
\text { 5. Pembesaran tulang } \\
\text { 6. Tidak teraba hangat pada sinovium } \\
\text { sendi terkena } \\
\text { 7. LED }<40 \mathrm{~mm} / \mathrm{jam} \\
\text { 8. RF }<1: 40 \\
\text { 9. Analisis cairan sinovium sesuai } \\
\text { OA }\end{array}$ \\
\hline
\end{tabular}

Kriteria diagnosis OA tangan berdasarkan klinis menurut ACR yaitu nyeri, ngilu atau kaku pada tangan dan paling sedikit 3 dari kriteria dibawah ini:

1. Pembengkakan jaringan keras dari 2 atau lebih sendi-sendi tangan di bawah ini:

- Sendi distal interfalang ke-2 dan ke-3

- Sendi proksimal interfalang ke-2 dan ke-3

- Sendi pertama karpometakarpofalang kedua tangan

2. Pembengkakan jaringan keras dari 2 atau lebih sendi distal interfalang

3. Kurang dari 3 pembengkakan sendi metakarpofalang

4. Deformitas sedikitnya pada 1 dari 10 sendisendi tangan pada kriteria 2 di atas (Indonesian Rheumatology Association, 2014).

Kriteria diagnosis OA panggul menurut

ACR berdasarkan kriteria klinis dan laboratoris yaitu nyeri pada sendi panggul/coxae dan paling sedikit salah 1 dari 2 kelompok kriteria di bawah ini:

1. Rotasi internal sendi panggul $<15^{\circ}$ disertai LED $\leq 45 \mathrm{~mm} / \mathrm{jam}$ atau fleksi sendi panggul $\leq$ $115^{\circ}$ (jika LED sulit dilakukan)

2. Rotasi internal sendi panggul $\geq 15^{\circ}$ disertai nyeri yang terkait pergerakan rotasi internal

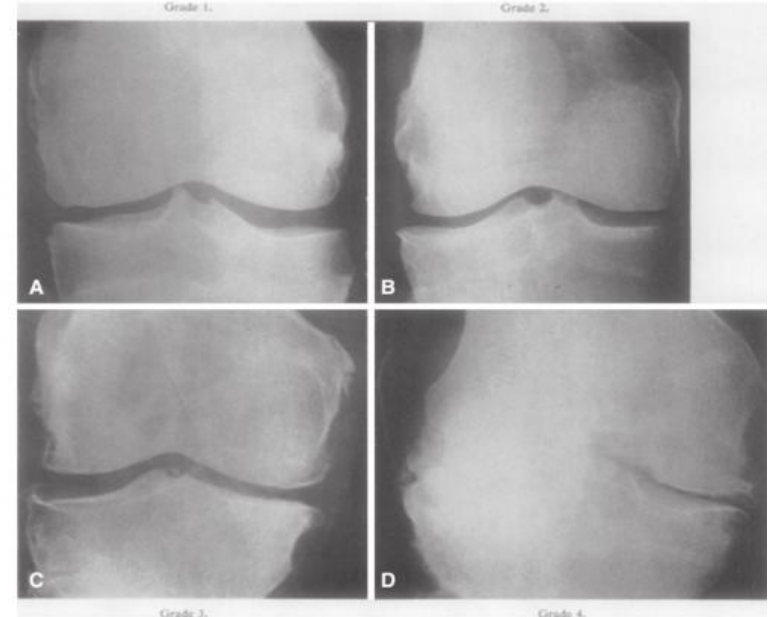

Gambar 1. Kellgren- Lawrence Scale

Sedangkan kriteria OA panggul berdasarkan kriteria klinis, laboratoris dan radiologis menurut ACR yaitu nyeri pada sendi panggul/coxae dan paling sedikit 2 dari 3 kriteria dibawah ini:

1. LED $<20 \mathrm{~mm}$ pada jam pertama

2. Osteofit pada femoral dan atau acetabular pada gambaran radiologis

3. Penyempitan celah sendi secara radiologis

Berdasarkan gambaran radiografi, osteoarthritis (OA) dikelompokkan menjadi 4 (empat) skala. Skala tersebut disebut juga Kellgren-Lawrence Scale. Kellgren-Lawrence Scale terdiri dari:

1. Skala 1 (Gambar A): penyempitan celah sendi yang masih diragukan dengan kemungkinan terbentuknya osteofit

2. Skala 2 (Gambar B): penyempitan celah sendi dengan pembentukan osteofit

3. Skala 3 (Gambar C): penyempitan celah sendi, pembentukan osteofit moderat, sklerosis dan kemungkinan deformitas pada ujung tulang

4. Skala 4 (Gambar D): pembentukan formasi osteofit yang besar, penyempitan 
celah sendi yang berat dengan sklerosis yang jelas, dan deformitas pada ujung tulang (Kohn, Sassoon, \& Fernando, 2016).

PRP adalah produk darah autolog yang mengandung growth factor dan konsentrasi trombositnya lebih tinggi dari konsentrasi normal. Misalnya jumlah trombosit normal 150.000-450.000, dapat dikatakan PRP jika jumlah trombositnya 4-5 kali diatas kadar tersebut. Prosedur persiapan PRP dimulai dengan pengambilan darah vena sebanyak $27 \mathrm{ml}$ lalu dimasukkan ke tiga tabung vacutainer $10 \mathrm{ml}$ yang mengandung natrium sitrat $0,106 \mathrm{M}$. Kemudian darah diaduk dengan hati-hati agar menyatu dengan antikoagulan, lalu sampel darah disentrifugasi selama 10 menit dengan dengan kecepatan $3200 \mathrm{rpm}$ pada $22^{\circ} \mathrm{C}$. Hasil dari sentrifugasi tersebut menghasilkan 3 lapisan yaitu lapisan inferior yang terdiri dari eritrosit, lapisan intermediet terdiri dari leukosit, dan lapisan superior yang terdiri dari plasma (Hussain, Johal, \& Bhandari, 2017; Raeissadat, et al., 2017).

Selanjutnya, buffy coat dan lapisan plasma disentrifugasi kembali selama 10 menit dengan kecepatan 1500 rpm untuk memisahkan leukosit. Setelah itu, darah disentrifugasi yang ketiga kalinya selama 10 menit dengan kecepatan 3200 rpm untuk mendapatkan 2 lapisan plasma yaitu pada bagian atas terdiri dari platelet-poor plasma dan bagian bawahnya yaitu PRP (Spaková, et al., 2012). Pada OA lutut, injeksi PRP bertujuan untuk mempromosikan tulang rawan memperbaiki dan meringankan gejala osteoartritik, berpotensi menunda kebutuhan untuk operasi penggantian sendi (Kavadar, Demircioglu, Celik, \& Emre, 2015). Terapi ini dapat diberikan dengan mudah dan tanpa efek samping yang parah pada pasien. Pasien yang dirawat dapat kembali normal setiap hari aktivitas tanpa kesulitan segera setelah infiltrasi (Cerza, et al., 2012).

Ketika PRP disuntikkan ke tempat yang terluka, trombosit diaktifkan oleh trombin endogen atau kolagen intraartikular. Setelah diaktifkan akan timbul sekresi growth factor dan mediator mediator inflamasi seperti platelet derived growth factor (PDGF), antagonis reseptor interleukin-1 (IL-1RA), soluble receptor of tumor necrosis factor (TNF-RI), tumor growth factor $\mathrm{p}$ (TGF-p), platelet factor 4 (PF4), vascular endotel growth factor (VEGF), epidermal growth factor (EGF), insulin growth factor (IGF), osteocalcin (Oc), osteonektin, fibrinogen, vitroneektin, bronkektin dan trombospondin (Knop, Paula, \& Fuller, 2015).

Antagonis reseptor IL-1 menghambat aktivasi gen NFnB, sitokin yang terlibat dalam proses apoptosis inflamasi. TGF-p1 juga bertindak sebagai faktor yang menghambat degradasi tulang rawan, mengatur dan meningkatkan ekspresi gen inhibitor jaringan metalloproteinases (TIMP-1) . Faktor-faktor lain seperti IGF-1, PDGF dan TGF-favor mendukung stabilisasi tulang rawan dengan mengendalikan fungsi metabolisme kondrosit dan tulang subkondral, mempertahankan homeostasis antara sintesis dan degradasi proteoglikan, dan merangsang proliferasi kondrosit. platelet growth factor juga dapat menstimulasi fibroblast sinovial untuk mensintesis asam hialuronat (Knop, et al., 2015).

Fungsi spesifik beberapa growth factor yang terkandung pada PRP adalah sebagai berikut:

1. Transforming growth factor beta berfungsi untuk menstimulasi proliferasi sel undifferentiated mesenkimal, regulasi endothelial, fibroblast dan mitogenesis osteoblastik, regulasi sintesis kolagen dan sekresi kolagen, regulasi efek mitogenic dari growth factor lain, menghambat proliferasi makrofag dan limfosit serta menstimulasi endothelial chemotaxis dan angiogenesis.

2. Basic fibroblast growth factor berfungsi untuk mendukung pertumbuhan dan diferensiasi kondroblas dan osteoblast, mitogenik untuk stem sel mesenkimal, kondrosit dan osteoblast.

3. Platelet derived growth factor berfungsi sebagai mitogenic untuk stem sel dan osteblas, memicu kemotaksis dan mitogenesis pada fibroblast atau sel otot polos, meregulasi sekresi kolagen dan sintesis kolagen dan menstimulasi kemsotaksis neutrophil.

4. Epidermal endothelial growth factor berfungsi untuk menstimulasi kemotaksis endotel atau angingogenesis, regulasi sekresi kolagen, menstimulasi epitel atau mitogenesis mesenkimal.

5. Vascular growth factor berfungsi untuk meningkatkan angiogenesis dan permeabilitas vaskuler, menstimulasi mitogenesis untuk sel endothelial.

6. Connective tissue growth factor berfungsi untuk mendukung angiogenesis, regenerasi kartilago, fibrosis dan adhesi platelet (Spaková, et al., 2012).

Lain halnya dengan PRP, asam hialuronat merupakan komponen alami kartilago dan cairan sinovial. Pada lutut orang dewasa yang normal, terdapat sekitar $2 \mathrm{ml}$ cairan sinovial dengan konsentrasi hialuronat 2,5 sampai $4 \mathrm{mg}$ per mililiter. Asam hialuronat berperan sebagai pelumas atau peredam kejut pada sendi. Injeksi 
hialuronat eksogen bisa disintesis dengan cara fermentasi bakteri atau diambil dari jaringan hewan. Pada terapi ini, pasien harus menghindari mengangkat beban berat hingga 48 jam pasca perawatan dan tidak ada kebutuhan rutin memakai analgesik setelahnya. Perbaikan yang terjadi setelah terapi asam hialuronat biasanya sekitar 5-24 minggu setelah injeksi dengan efek residu masih ada pada minggu ke 24. Efek samping yang ditimbulkan dapat ringan hingga berat seperti rasa sakit di tempat suntikan, pembengkakan, infeksi, reaksi pseudoseptik, hingga efek gastrointestinal dan kardiovaskular pernah dilaporkan terjadi (Hunter, 2015).

Asam hialuronat berperan dalam metabolisme sendi, dimana asam hialuronat akan merangsang metabolisme kondrosit dan sintesis komponen matriks tulang rawan ( $\mathrm{Yu}, \mathrm{Xu}$, Huang, \& Liu, 2018). Terdapat dua jenis HA yang tersedia saat ini, yaitu HA dengan low molecular weight (LMW) (berat molekul 0,5-3,6 juta Da) dan HA dengan high molecular wight (HMW) sekitar 6 juta Da (Jesalpura \& Gajjar, 2017). Injeksi HA dapat meningkatkan lubrikasi pada sendi (Han, et al., 2018).

Pada tahun 2013, American Academy of Orthopaedic Surgeons (AAOS) tidak merekomendasikan penggunaan viskosuplementasi pada kondisi OA simptomatik. Berdasarkan penelitian yang telah dilakukan didapatkan bahwa penggunaan injeksi asam hialuronat dengan berat molekul tinggi memberikan perbaikan signifikan, tetapi jika dibandingkan dengan berat molekul rendahsedang hasilnya tidak signifikan. Pemberian viskosuplemen ini juga paling efektif jika diberikan pada OA tahap awal (mild-moderate) (Wijaya, 2018).

Berdasarkan rekomendasi Indonesian Rheumatology Association (IRA), untuk HA jenis low molecular weight diberikan berturutturut 5 sampai 6 kali injeksi dengan interval satu minggu sebanyak 2 sampai 2,5 ml. Sedangkan untuk HA dengan high molecular wight diberikan 1 kali untuk jenis high molecular weight, dan 2 kali pemberian dengan interval 1 minggu untuk jenis tipe campuran. Teknik injeksi harus aseptik, tepat dan benar. Komplikasi yang dapat timbul akibat injeksi seperti artritis septik, nekrosis jaringan dan abses steril (Indonesian Rheumatology Association, 2014).

Vaquerizo, et al. melakukan penelitian mengenai perbandingan injeksi intraartilukular PRP dan asam hialuronat, dari penelitian tersebut didapatkan 96 pasien yang dievaluasi selama 48 minggu. PRP menunjukkan respons yang lebih baik di semua parameter yang dianalisis, baik pada 24 minggu maupun 48 minggu. Parameter yang dianalisis yaitu skor Western Ontario and McMaster Universities Osteoarthritis (WOMAC) score dan Lequense index. Skor WOMAC terdiri dari skor nyeri, skor fungsi fisik, skor kekakuan. Sedangkan Lequense index digunakan untuk menilai keparahan osteoarthritis yang terdiri dari 3 subscale yaitu nyeri atau tidak nyaman, jarak berjalan maksimum dan aktivitas kehidupan sehari-hari atau fugsi fisik (Vaquerizo et al., 2013).

Interpretasi dari indeks Lequense yaitu sebagai berikut:

- Minimal nilai dari setiap parameter: 0

- Maksimal nilai dari setiap parameter: 8

- Minimal nilai dari indeks Lequesne: 0

- Maksimal nilai dari indeks Lequesne: 24 (Indonesian Rheumatology Association, 2014).

Tabel 2. Indeks Lequense

\begin{tabular}{cc}
\hline $\begin{array}{c}\text { Nilai Indeks } \\
\text { Lequense }\end{array}$ & Derajat Osteoarthritits \\
\hline 1 & Normal \\
$1-4$ & Ringan \\
$5-7$ & Sedang \\
$8-10$ & Berat \\
$11-13$ & Sangat Berat \\
$>14$ & Berat Sekali (Extremely Severe) \\
\hline
\end{tabular}

Dalam menilai WOMAC skor diperlukan kuisioner kepada pasien untuk mengetahui skala dari tiap kriteria. Contoh kriteria yang dinilai dalam WOMAC skor disajikan tabel berikut.

\section{Tabel 3. Kriteria Skor WOMAC}

\begin{tabular}{ll}
\hline Nyeri & - Berjalan \\
& - Menaiki tangga \\
& - Pada malam hari \\
& - Saat istirahat \\
- Membawa beban \\
\hline Kekakuan & - Kekakuan yang terjadi di pagi hari \\
& - Kekakuan yang terjadi di kemudian hari \\
\hline Fungsi & - Menuruni tangga \\
Fisik & - Menaiki tangga \\
& - Berdiri dari duduk \\
& - Berdiri \\
& - Berbelok di lantai \\
& - Berjalan diatas permukaan yang datar \\
& - Masuk atau keluar mobil \\
& - Pergi berbelanja \\
- Menaruh kaos kaki & - Berbaring di tempat tidur \\
& - Membuk kaos kaki \\
- Bangkit dari tempat tidur \\
- Masuk/keluar bak tempat mandi \\
- Membuka mata \\
- Duduk \\
- Keluar/masuk toilet \\
- Melakukan tugas rumah ringan \\
- Melakukan tugas rumah berat
\end{tabular}


Dai, et al mengevaluasi efikasi dan kemanan injeksi PRP untuk terapi osteoarthritis menggunakan teknik metaanalisis. Penelitian ini menggunakan 10 randomized controlled trial (RCT) dengan total 1069 pasien. Pada 6 bulan post injeksi, HA dan PRP memiliki efek yang serupa dalam mengurangi nyeri dan meningkatkan fungsional, namun pada 12 bulan post injeksi, PRP memiliki hasil yang lebih baik dibandingkan dengan injeksi asam hialuronat berdasarkan skor WOMAC. Penelitian ini juga membandingkan efektivitas injeksi PRP dengan injeksi saline. Hasil yang didapatkan adalah PRP lebih efektif dalam mengurangi nyeri dan meningkatkan fungsional sendi pada bulan ke-6 dan ke-12 post injeksi PRP. Dari penelitian tersebut dapat disimpulkan bahwa injeksi intraartikular PRP lebih berguna dalam mengatasi nyeri dan perbaikan fungsi sendi pasien $\mathrm{OA}$ dibandingkan dengan injeksi asam hialuronat atau saline pada 1 tahun post injeksi (Dai, et al., 2017).

Say, et al melakukan penelitian yang bertujuan untuk membandingkan efek injeksi PRP dengan asam hialuronat di lutut pasien yang menderita osteoarthritis, pada penelitian ini menggunakan 90 sampel dimana 45 sampel diberikan injeksi PRP dan 45 sampel diberikan asam hialuronat. Penelitian ini menggunakan knee injury osteoarthritis outcome score (KOOS) dan visual pain scale untuk mengetahui efektivitas kedua terapi tersebut. Dari penelitian tersebut, diperoleh hasil bahwa pemberian PRP memiliki efek yang signifikan lebih baik dibandingkan asam hialuronat pada follow up 3 bulan dan 6 bulan serta PRP juga memiliki biaya aplikasi yang lebih murah (Say, Gürler, Yener, Bülbül, \& Malkoc, 2013).

Berdasarkan penelitian yang dilakukan oleh Kavadar, et al. dapat disimpulkan bahwa PRP adalah terapi yang efektif untuk perbaikan status fungsional dan nyeri pada osteoarthritis lutut sedang dan diberikan minimal dua kali suntikan. Pada penelitian ini pasien osteoarthritis derajat 3 dibagi menjadi 3 kelompok yaitu kelompok pertama yang hanya mendapat satu kali injeksi PRP, kelompok kedua mendapat 2 kali injeksi PRP dalam 2 minggu terpisah dan kelompok ketiga mendapat injeksi PRP 3 kali dalam interval 2 minggu. Penilaian dilakukan menggunakan skor WOMAC total, WOMAC nyeri, WOMAC stiffness, dan WOMAC fungsional (Kavadar, et al., 2015).
Annaniemi, Pere dan Giordano melakukan penelitian untuk membandingkan platelet rich plasma dengan asam hialuronat dalam mengurangi gejala dan waktu untuk arthoplasty. Dari penelitian yang dilakukan dapat disimpulkan bahwa injeksi intraatikular platelet rich plasma menunjukkan hasil yang lebih baik dibandingkan asam hialuronat pada OA lutut dan PRP juga dapat memperpanjang waktu arthroplasty. Selain itu PRP dapat menjadi pilihan terapi untuk pasien OA yang tidak berespon terhadap terapi konvensional (Annaniemi, Pere, \& Giordano, 2018).

Penelitian ini diikuti oleh 190 pasien dimana 94 pasien mendapat terapi injeksi PRP dan 86 pasien mendapat terapi injeksi asam hialuronat. Penilaian dengan menggunakan WOMAC skor, visual analog scale (VAS), dan range of motion (ROM) yang dinilai saat sebelum injeksi, hari ke-15, 6 bulan, 12 bulan dan saat terakhir follow up. Berdasarkan pengalaman, tiga kali injeksi platelet rich plasma diberikan pada interval 2 minggu mungkin dapat digunakan sebagai terapi yang optimal (Annaniemi, et al., 2018).

Cerza, et al. melakukan penelitian untuk membandingkan injeksi asam hialuronat dengan injeksi PRP sebagai terapi gonarthrosis (deformitas pada sendi lutut). Sampel penelitian ini terdiri dari 120 pasien yang terdiagnosis secara klinis dan radiologis berdasarkan Kellgren-Lawrence Scale. Penelitian ini membagi pasien menjadi 2 kelompok yaitu kelompok pertama, 60 pasien menerima 4 kali injeksi PRP dan kelompok kedua, 60 pasien menerima 4 kali injeksi asam hialuronat. Semua pasien dievaluasi menggunakan skor WOMAC sebelum diberikan injeksi, pada minggu ke-4, ke-12, dan ke-24 setelah injeksi pertama. Dari hasil penelitian ini dapat disimpulkan bahwa terapi PRP menunjukkan hasil klinis yang lebih baik dibandingkan dengan terapi menggunakan HA. Dari penelitian ini juga diketahui bahwa pada gonarthrosis derajat III, terapi dengan HA menjadi kurang efektif. Sedangkan terapi dengan PRP efektif untuk semua derajat (Cerza, et al., 2012).

\section{SIMPULAN}

Platelet rich plasma lebih efektif dibandingkan dengan asam hialuronat sebagai terapi osteoarthritis. 


\section{DAFTAR PUSTAKA}

Annaniemi, J., Pere, J., \& Giordano, S. (2018). Platelet-Rich Plasma versus hyaluronic acid injections for Knee osteoarthritis: a Propensity-score analysis. Scandinavian Journal of Surgery, 1-9.

Arden, N., \& Nevitt, M. C. (2006). Osteoarthritis: Epidemiology. Best Practice and Research: Clinical Rheumatology, 20(1), 3-25.

Cerza, F., Carnı, S., Carcangiu, A., Vavo, I. Di, Schiavilla, V., Pecora, A., Ciuffreda, M. (2012). Comparison Between Hyaluronic Acid and Platelet-Rich Plasma, Intraarticular Infiltration in the Treatment of Gonarthrosis. The American Journal of Sport Medicine, 40(12), 2822-2827.

Conte, F. D. P., Barja-Fidalgo, C., Verri, W. a, Cunha, F. Q., Rae, G. a, Penido, C., \& Henriques, M. D. G. M. O. (2008). Osteoarthritis. In Arthritis by the numbers (pp. 9-17). Atlanta: Arthritis Foundation.

Dai, W.-L., Zhou, A.-G., Zhang, H., \& Zhang, J. (2017). Efficacy of Platelet-Rich Plasma in the Treatment of Knee Osteoarthritis: A Meta-analysis of Randomized Controlled Trials. Arthroscopy: The Journal of Arthroscopic and Related Surgery, 33(3), 1-12.

Fransen, M., Bridgett, L., March, L., Hoy, D., Penserga, E., \& Brooks, P. (2014). The epidemiology of osteoarthritis in asia. Best Practice and Research: Clinical Rheumatology, 28(1), 5-15.

Han, Y., Huang, H., Pan, J., Lin, J., Zeng, L., Liang, G., Liu, J. (2018). Comparison of platelet-rich plasma vs hyaluronic acid injections in patients with knee osteoarthritis. Medicine, 97(44), 10-13.

Hunter, D. J. (2015). Viscosupplementation for osteoarthritis of the knee. $N$ Engl J Med, 372(11), 1040-1047.

Hussain, N., Johal, H., \& Bhandari, M. (2017). An evidence-based evaluation on the use of platelet rich plasma in orthopedics-a review of the literature. Sicot-J, 3, 57.

Indonesian Rheumatology Association. (2014). Diagnosis dan Penatalaksanaan Osteoartritis. Indonesian Rheumatology Association.

Jesalpura, B. H., \& Gajjar, S. H. (2017). Intra articular hyaluronic acid injection, is it a wastage of money or justified?. The American Journal of Sport Medicine, 3(4), 795-799.

Kavadar, G., Demircioglu, D. T., Celik, M. Y., \&
Emre, T. Y. (2015). Effectiveness of platelet-rich plasma in the treatment of moderate knee osteoarthritis: a randomized prospective study. Journal of Physical Therapy Science, 27(12), 3863-3867.

Knop, E., Paula, L. E. De, \& Fuller, R. (2015). Platelet-rich plasma for osteoarthritis treatment. Revista Brasileira de Ortopedia (English Edition), 56(2), 152-164.

Kohn, M. D., Sassoon, A. A., \& Fernando, N. D. (2016). Classifications in Brief. Clinical Orthopaedics and Related Research ${ }^{\circledR}$, 474(8), 1886-1893.

Raeissadat, S. A., Rayegani, S. M., Ahangar, A. G., Abadi, P. H., Mojgani, P., \& Ahangar, O. G. (2017). Efficacy of Intra-articular Injection of a Newly Developed Plasma Rich in Growth Factor (PRGF) Versus Hyaluronic Acid on Pain and Function of Patients with Knee Osteoarthritis: A Single-Blinded Randomized Clinical Trial. Clinical Medicine Insights: Arthritis and Musculoskeletal Disorders, 10, 1-9.

Sadabad, H. N., Behzadifar, M., Arasteh, F., Behzadifar, M., Reza, H., Management, H., Sciences, M. (2016). Efficacy of Platelet-Rich Plasma versus Hyaluronic Acid for treatment of Knee Osteoarthritis: A systematic review and meta-analysis. Electronic Physician, 8(3), 2115-2122.

Say, F., Gürler, D., Yener, K., Bülbül, M., \& Malkoc, M. (2013). Platelet-rich plasma injection is more effective than hyaluronic acid in the treatment of knee osteoarthritis. Acta Chirurgiae Orthopaedicae et Traumatologiae Cechoslovaca, 80(4), 278283.

Say, F., \& Yener, K. (2013). Platelet-Rich Plasma Injection Is More Effective than Hyaluronic Acid in the Treatment of Knee Osteoarthritis. Acta Chirurgiae Orthopaedicae et Traumatologiae Cechoslovaca, 80, 278-283.

Soeroso, J., Isbagio, H., Kalim, H., Broto, R., \& Pramudiyo, R. (2009). Osteoartritis. In S. Setiati, I. Alwi, A. W. Sudoyo, M. Simadibrata K, B. Setiyohadi, \& A. F. Syam (Eds.), Buku Ajar Ilmu Penyakit Dalam (pp. 1825-1829). Jakarta: Pusat Penerbitan Departemen Ilmu Penyakit Dalam Fakultas Kedokteran Universitas Indonesia.

Soeroso, J., Isbagio, H., Kalim, H., Broto, R., \& Pramudiyo, R. (2017). Osteoartritis. In S. Setiati, I. Alwi, A. W. Sudoyo, M. 
Simadibrata K, B. Setiyohadi, \& A. F. Syam (Eds.), Buku Ajar Ilmu Penyakit Dalam (6th ed., pp. 1825-1829). Jakarta: Interna Publishing.

Spaková, T., Rosocha, J., Lacko, M., Harvanová, D., \& Gharaibeh, A. (2012). Treatment of Knee Joint Osteoarthritis with Autologous Platelet-Rich Plasma in Comparison with Hyaluronic Acid. American Journal of Physical Medicine \& Rehabilitation, 91(5), 411-417.

Vaquerizo, V., Plasencia, M. Á., Arribas, I., Seijas, R., Padilla, S., Orive, G., \& Anitua, E. (2013). Comparison of Intra-Articular Injections of Plasma Rich in Growth Factors (PRGF-Endoret) Versus Durolane Hyaluronic Acid in the Treatment of Patients With Symptomatic Osteoarthritis:
A Randomized Controlled Trial. Arthroscopy: The Journal of Arthroscopic and Related Surgery, 29(10), 1635-1643.

Widyadharma, I. P. E. (2013). The role of Platelet-rich Plasma in Pain Management. In Update in Pain Management. Banda Aceh.

Wijaya, S. (2018). Osteoartritis Lutut. $C D K-265$, 45(6), 424-429.

Yu, W., Xu, P., Huang, G., \& Liu, L. I. N. (2018). Clinical therapy of hyaluronic acid combined with platelet - rich plasma for the treatment of knee osteoarthritis. Experimental and Therapeutic Medicine, 16, 2119-2125.

Zhang, Y., \& Jordan, J. M. (2011). Epidemiology of Osteoarthritis. Clin Geriatr Med, 26(154), 217-226. 